DOI 10.4467/12332135KRA.21.009.14688

\title{
Sprawozdanie ze stanu inwestycji budowy nowej siedziby dla Archiwum Narodowego w Krakowie Oddzial w Nowym Sączu
}

Starania o przyznanie środków na budowę nowej siedziby dla nowosądeckiego oddziału Archiwum Narodowego w Krakowie rozpoczęły się w 2017 r. Potrzeba posiadania nowego budynku, zbudowanego od podstaw i dostosowanego do profilu działalności Archiwum, wynikała po pierwsze z braku wystarczającej przestrzeni magazynowej w dotychczasowej siedzibie Oddziału, po drugie z niezwykle skomplikowanej sytuacji lokalowej Archiwum w Nowym Sączu oraz Nowym Targu. Najpierw w 2011 r. zlikwidowano oddział aktowy w Nowym Targu i akta przewieziono do Ekspozytury Archiwum w Spytkowicach koło Zatoru. Następnie w 2017 r. (pismo z 8 maja 2017 r.) Archiwum otrzymało od Prokuratury Okręgowej w Nowym Sączu, od której wynajmowało pomieszczenia przy ul. Jagiellońskiej 56, zawiadomienie o konieczności opuszczenia lokalu. Formalne wypowiedzenie najmu zostało wystosowane w dniu 20 lipca 2018 r. Dodatkowo w dniu 21 listopada 2018 r. Archiwum otrzymało od właściciela wypowiedzenie najmu drugiego zajmowanego lokalu w Nowym Sączu - przy ul. Żeglarskiej 9a. W tym czasie trwała już budowa nowej centralnej siedziby dla Archiwum w Krakowie przy ul. Rakowickiej 22E, mająca się zakończyć w 2020 r. Jako tymczasowy środek zaradczy udało się w dniu 12 grudnia 2018 r. wynająć od PT Dystrybucja SA budynek przy ul. Jagiellońskiej 54 w Nowym Sączu (sąsiedni do Prokuratury), gdzie po adaptacji pomieszczeń na magazyny, gabinety i czytelnię urządzono w 2019 r. siedzibę Oddziału. Uznano jednak, że długo w tym stanie tymczasowości Oddział nie może funkcjonować. Wciąż np. z powodu braku wystarczającej ilości magazynów nie było możliwe przejmowanie nowych materiałów archiwalnych. Siedziba nie spełniała także warunków do prowadzenia działalności popularyzatorskiej (pokazy, zajęcia, wystawy) z prawdziwego zdarzenia.

Wobec powyższego w grę wchodziły tylko dwa rozwiązania: likwidacja Oddziału i przeniesienie zasobu do własnego budynku w Krakowie (w bliższym oddziale w Tarnowie nie ma w magazynach miejsca na całość akt z Nowego Sącza) albo budowa zupełnie od podstaw nowego budynku w Nowym Sączu, gdzie zmieściłby się cały dotychczasowy zasób Oddziału wraz z planowanymi nabytkami i całością akt byłego Oddziału w Nowym Targu. Naczelna Dyrekcja Archiwów Państwowych przychyliła się do argumentacji dyrektora Archiwum Narodowego w Krakowie, że z uwagi na odległość Nowego Sącza od Krakowa przeniesienie zasobu do tego ostatniego w praktyce uniemożliwi korzystanie z akt przez lokalną społeczność. W 2018 r. otwarto w Ministerstwie Kultury i Dziedzictwa Narodowego tytuł inwestycyjny dla przedsięwzięcia i wykonano pierwsze kroki do rozpoznania możliwości przeprowadzenia i sfinansowania budowy. Przełomowe znaczenie miała 
niezwłoczna reakcja i wsparcie okazane przez władze samorządowe Nowego Sącza. Prezydent Nowego Sącza Ryszard Nowak jako zarządca zasobu nieruchomości Skarbu Państwa na terenie miasta bardzo szybko, bo już decyzją z 7 maja 2018 r., przydzielił Archiwum nieruchomość oznaczoną nr 1/23 obręb 96, położoną przy ul. 29 Listopada $12 \mathrm{w}$ Nowym Sączu, z przeznaczeniem na budowę nowej siedziby. Dzięki temu wniosek Archiwum o przyznanie środków wraz z propozycją koncepcji nowego budynku mógł być rozpatrzony pozytywnie przez Ministra Kultury i Dziedzictwa Narodowego. W kolejnych latach sfinansowano prace projektowe oraz zagwarantowano środki na kolejne wydatki, aż ostatecznie w piśmie z 11 marca 2021 r. Wicepremier Minister Kultury, Dziedzictwa Narodowego i Sportu - Piotr Gliński wyraził zgodę na rozpoczęcie budowy i przyznanie w sumie $36630000 \mathrm{zł}$ na realizację całej inwestycji.

W ramach prac koncepcyjnych korzystano szeroko z doświadczeń zdobytych podczas inwestycji prowadzonej przy ul. Rakowickiej 22E w Krakowie. Archiwum przygotowało we własnym zakresie w sierpniu 2019 r. ,Założenia do koncepcji architektoniczno-funkcjonalnej budynku wraz z wytycznymi branżowymi". Następnie w dniu 22 sierpnia 2019 r. podpisano umowę ze Studiem Architektonicznym Wojciech Kozub na przygotowanie samej „Koncepcji architektoniczno-funkcjonalnej” jako podstawy do wyboru pracowni projektowej. Umowę z biurem architektonicznym na wykonanie dokumentacji projektowej podpisano, po przejściu procedury przetargowej, w dniu 24 lutego 2020 r. z Pracowniami Konserwacji Zabytków „Arkona” Sp. z o.o. Decyzję Prezydenta Miasta Nowego Sącza o pozwoleniu na budowę uzyskano w dniu 10 września 2020 r., dokumentację projektową odebrano w listopadzie 2020 r., a w dniu 25 listopada 2021 r. podpisano z ESTCOST Michał Miedziejewski umowę na wielobranżową weryfikację projektu - ukończoną w styczniu $2021 \mathrm{r}$. Na podstawie tak sporządzonej dokumentacji ogłoszono przetargi na wybór Inwestora Zastępczego i Generalnego Wykonawcy inwestycji. Po sprawnym ukończeniu obydwu postępowań podpisano odpowiednio umowy: z dnia 22 marca $2021 \mathrm{r}$. z ECM Group Polska SA na sprawowanie funkcji Inwestora Zastępczego oraz z dnia 16 kwietnia 2021 r. ze Skanska SA na wykonanie robót budowlanych. W ten sposób w czerwcu 2021 r. przy ul. 29 Listopada 12 mogły się faktycznie zaczać prace budowlane. Termin ich zakończenia przewidziano w grudniu $2023 \mathrm{r}$.

W trakcie prac projektowych zdecydowano, że nowy budynek powinien pomieścić cały dotychczasowy zasób Oddziału w Nowym Sączu (ok. 1800 mb), zasób byłego Oddziału w Nowym Targu (ok. $1200 \mathrm{mb}$ ), cały nadzorowany zasób archiwalny planowany do przejęcia od innych jednostek (obecnie $3629 \mathrm{mb}$ ) oraz zapas na nowe nieprzewidziane nabytki. Należało ponadto uwzględnić miejsce na przyszłe inwestycje. Według projektu wykonawczego magazyny w nowym obiekcie pomieszczą zatem w sumie $9432 \mathrm{mb}$ standardowych akt. Jednocześnie projekt umożliwia późniejszą rozbudowę w poziomie (dobudowa na dalszej części działki) lub pionie (nadbudowa kolejnej kondygnacji na górze). Sam gmach ma powierzchnię zabudowy równą $1525,68 \mathrm{~m}^{2}$, powierzchnię użytkową: $2538,70 \mathrm{~m}^{2}$ (w tym 900,69 $\mathrm{m}^{2}$ na część biurową) i kubaturę: 15 735,08 $\mathrm{m}^{3}$ (w tym 240,79 $\mathrm{m}^{3}$ na budynek techniczno-gospodarczy i stację trafo). Z uwagi na podłużny kształt nieruchomości obiekt przyjmie postać dwukondygnacyjnego prostopadłościanu (z niewielką liczbą załamań), długiego na 34,4 m, szerokiego na 16,3 m i wysokiego na 10,5 m. Krótszym bokiem zwrócony jest do ul. 29 Listopada. Podział na segment biurowy i magazynowy - zasada 
stosowana na wzór siedziby w Krakowie - tym razem nie jest odzwierciedlony w jednolitej bryle budynku. O ile jednak część biurowa, usytuowana bliżej ulicy i głównego wejścia do budynku, posiada przede wszystkim szklaną fasadę zapewniającą wystarczającą ilość światła dziennego dla pracowników i klientów, o tyle część magazynowa, zajmująca ok. 2/3 całej bryły, położona z tyłu obiektu, nie posiada żadnych otworów okiennych i objęta jest fasadą z paneli aluminiowych. Współgra to z głównymi założeniami filozofii budynku, zakładającymi odseparowanie wnętrza magazynów od zmiennych warunków zewnętrznych i ułatwienie zachowania stabilnych warunków klimatycznych wewnątrz. Część biurowa z kolei, przeznaczona dla użytkowników, posiada na parterze dużą strefę publiczną, tj. przeszklony hol oraz salę konferencyjną na co najmniej 90 miejsc, z możliwością połączenia, po zasunięciu ścianki mobilnej, z czytelnią na maksymalnie ok. 50 miejsc w jedną wielką przestrzeń wystawowo-konferencyjną. Na pierwszym piętrze znajdują się pomieszczenia do pracy z aktami, w tym pracownia digitalizacji, strefa sanitarna, serwerownia oraz sale do zajęć lekcyjnych. W magazynach zaplanowano umieszczenie regałów jezdnych o wysokości dogodnej do korzystania bez użycia drabin, a także wzmocnione stropy i podłogę z żywicy epoksydowej.

Podstawowym założeniem projektowym dla budynku jest zapewnienie odpowiednich, stabilnych warunków temperaturowych i wilgotnościowych we wnętrzu magazynów archiwalnych. Osiągnięto to przede wszystkim poprzez izolację ścian pozbawionych okien i zapewnienie możliwości funkcjonowania wentylacji na tzw. „obiegu zamkniętym”, tj. bez wymiany powietrza z zewnątrz i konieczności stałego oddziaływania na nie w celu uzyskania pożądanych właściwości. Za pomocą centralnych jednostek osuszacza, nagrzewnicy i chłodnicy powietrze krążące w układzie wentylacji pomiędzy centralną a magazynami osiąga wybrane parametry i wprowadza je do pomieszczeń, po czym tylko koryguje niewielkie wahania temperatury i wilgotności. W budynku występuje efekt tzw. „termosu”, czyli na tyle duża bezwładność klimatyczna w środku, że wszelkie zmiany na zewnątrz działają z dużym opóźnieniem i w wypłaszczony sposób. Jednocześnie jako źródło ciepła i chłodu przewidziano tylko i wyłącznie pompy ciepła (jednostki gruntowe i powietrzne). Dookoła budynku wykonanych zostanie ok. 20 odwiertów o głębokości ok. $100 \mathrm{~m}$, które dostarczą czynnik o stałej temperaturze między 10 a $15^{\circ} \mathrm{C}$. W lecie zapewni to chłodzenie obiektu, w zimie umożliwi odpowiednie działanie sprężarek w pompach. Jest to najbardziej ekonomiczny ze znanych obecnie sposobów ogrzewania i klimatyzacji budynków, działający już w siedzibie Archiwum przy ul. Rakowickiej 22E w Krakowie. W magazynach zastosowano również nowoczesny system przeciwpożarowy, tzw. „mgły wodnej”. Zakłada on brak wody w instalacjach w pomieszczeniach (w celu wyeliminowania ryzyka zalania) do czasu zadziałania alarmu przeciwpożarowego. Zraszacze uruchomią się tylko w miejscu najwyższej temperatury, czyli najbliżej źródła ognia, tak aby ograniczyć straty spowodowane przez akcję gaśniczą. Wspomnieć należy również o nowoczesnym zarządzaniu wszystkimi instalacjami (elektryczne, sanitarne, teletechniczne, przeciwpożarowe itd.) w budynku przez system BMS (building management system) oraz o panelach fotowoltaicznych na dachu, które zapewnią część energii elektrycznej dla budynku. W tylnej części działki zaprojektowano budynek techniczny ze stacją transformatorową oraz część zieloną $\mathrm{z}$ alejkami spacerowymi. 
Po zawarciu 16 kwietnia 2021 r. umowy na wykonanie robót budowlanych Generalny Wykonawca przystąpił niezwłocznie do organizacji placu budowy oraz zaplecza biurowo-technicznego. Niestety od razu nastąpiła kolizja interesów budowy z inną inwestycją prowadzoną przez Miejski Zarząd Dróg w Nowym Sączu, czyli remontem i przebudową ul. 29 Listopada. Z powodu prac drogowych na ulicy dostęp ciężkim sprzętem na plac naszej budowy możliwy stał się dopiero w czerwcu 2021 r. i wtedy też zaczęły się właściwe roboty budowlane. W ciągu miesiąca wykonano wszystkie potrzebne wykopy i roboty ziemne, po czym Wykonawca przystąpił do robót fundamentowych i wznoszenia konstrukcji żelbetowej całego obiektu. Całość konstrukcji w stanie surowym otwartym ukończono w listopadzie. Jednocześnie w październiku przystąpiono do wznoszenia fasady szklanej w celu zamknięcia wszystkich otworów przed porą zimową, co umożliwi kontynuowanie wówczas prac wewnątrz budynku. W tym samym czasie rozpoczęto odwierty pod sondy głębinowe oraz wznoszenie budynku gospodarczego i stacji trafo. Uruchomienie stacji transformatorowej planowane jest na maj 2022 r. Natomiast do końca bieżącego roku wszystkie odwierty powinny zostać ukończone. Przed końcem roku planowane jest również rozpoczęcie montażu izolacji oraz fasady budynku magazynowego. Realizację harmonogramu prac, przewidującego zakończenie robót w IV kwartale 2023 r., uznać należy za niezagrożoną, a nawet, jeżeli nie pojawią się zasadnicze przeszkody, możliwe jest przyspieszenie robót i wcześniejsze ich zakończenie w pierwszej połowie 2023 r.

Pawet Ząbczyński Archiwum Narodowe w Krakowie 